WCER Working Paper No. 2009-6

August 2009

\title{
Tracking and Inequality: \\ New Directions for Research and Practice
}

\author{
Adam Gamoran \\ Department of Sociology/ \\ Wisconsin Center for Education Research \\ University of Wisconsin-Madison \\ gamoran@ssc.wisc.edu
}

\section{GTWCER}

Wisconsin Center for Education Research

School of Education • University of Wisconsin-Madison • http://www.wcer.wisc.edu/ 
Copyright (C) 2009 by Adam Gamoran

All rights reserved.

Readers may make verbatim copies of this document for noncommercial purposes by any means, provided that the above copyright notice appears on all copies.

WCER working papers are available on the Internet at http://www.wcer.wisc.edu/publications/ workingPapers/index.php. Recommended citation:

Gamoran, A. (2009). Tracking and inequality: New directions for research and practice (WCER Working Paper No. 2009-6). Madison: University of Wisconsin-Madison, Wisconsin Center for Education Research. Retrieved [e.g., August 20, 2009,] from http://www.wcer.wisc.edu/publications/workingPapers/papers.php 


\section{Tracking and Inequality: New Directions for Research and Practice}

\section{Adam Gamoran}

For more than a century, educators and researchers have debated the merits of separating students into different tracks, classes, and groups according to their purported interests and abilities (for historical perspectives, see Powell, Farrar, \& Cohen, 1985; Oakes, Gamoran, \& Page, 1992; Loveless, 1998, 1999; Oakes, 2005). The practice, known as tracking and ability grouping in the U.S. and streaming and setting in the U.K., is intended to create conditions in which teachers can efficiently target instruction to students' needs. ${ }^{1}$ Despite this intended benefit, tracking has been widely criticized as inegalitarian because students in high tracks tend to widen their achievement advantages over their low-track peers, and because measures of school performance that are commonly used to assign students to tracks typically coincide with the broader bases of social disadvantage such as race/ethnicity and social class, leading to economically and/or ethnically segregated classrooms. Yet tracking has been highly resistant to lasting change and remains in wide use in various forms in the U.S., the U.K., and school systems around the world.

Although struggles over tracking involve instructional and political challenges that play out in schools and classrooms, the persisting debate reflects not only local concerns but also broader tensions inherent in education systems (Oakes et al., 1992). On the one hand, schools are charged with providing all students with a common framework of cognitive and social skills essential for full participation in the civic and economic activities of adult society. On the other hand, schools are structured to sort and select students for different trajectories aligned with their varied orientations and capacities. This ongoing tension between commonality and differentiation is at the heart of the tracking debate: Is the purpose of schooling to provide all students with a common socialization? Or is it to differentiate students for varied futures? The former aim is consistent with mixed-ability teaching, whereas the latter is consistent with tracking, and the debate has no simple resolution because school systems embody both goals.

Building on past studies, recent work on tracking has advanced in three areas that indicate promising new directions for research and practice. First, new international scholarship has extended knowledge about the consequences of tracking for student achievement to contexts beyond the U.S. and U.K., where most prior research had been conducted. Second, recent studies of attempts to reduce or eliminate tracking and ability grouping have yielded important insights

This paper was prepared for the The Routledge International Handbook of the Sociology of Education, edited by Michael W. Apple, Stephen J. Ball, and Luis Armand Gandin. New York: Routledge, in press. The author is grateful for helpful research assistance from Michelle Robinson.

${ }^{1}$ U.S. writers often use the terms tracking and ability grouping interchangeably. For brevity, I use the single term tracking to capture all the various forms of structural differentiation for instruction. When distinguishing among different forms, I use the term tracking to refer to the practice of dividing students into separate classes (or clusters of classes) for all of their academic subjects, and the term ability grouping to mean the division of students into classes on a subject-by-subject basis. This use parallels the meanings of the terms streaming and setting in the U.K. I use the term within-class ability grouping to refer to the use of instructional groups within class for a particular subject and between-school grouping to refer to systems in which students are assigned to separate schools targeted to different futures based on academic performance. 
about why tracking is resistant to change and how some of the obstacles to detracking may be surmounted. Third, a new wave of research on classroom assignment and instruction has pointed toward approaches that, while not resolving the tension between commonality and differentiation, may capture the benefits of differentiation for meeting students' varied needs without giving rise to the consequences for inequality that commonly accompany tracking and ability grouping. These findings, in turn, call for new research and experimentation in practice.

Before turning to these latest findings, I summarize the earlier literature on the effects of grouping and tracking on student achievement. This research has been well covered in prior reviews (e.g., Kulik \& Kulik, 1982; Slavin, 1987, 1990; Gamoran \& Berends, 1987; Oakes et al., 1992; Harlen \& Malcolm, 1997; Hallam, 2002; Gamoran, 2004), but I begin with it here because it sets the stage for the promising work of the present and the new directions for the future. Thus, the remainder of this paper is divided into four sections: (a) a review of findings about tracking and achievement that links work from the 1970s, 1980s, and 1990s to updated studies in the same vein; (b) a discussion of recent international research on tracking, both between and within schools; (c) an analysis of new studies of efforts to reduce or eliminate tracking; and (d) a conclusion calling for new research and practice based on the latest findings.

\section{Tracking and Achievement: Increased Inequality Without Benefits to Productivity}

Following Gamoran and Mare (1989), one may distinguish two possible consequences of tracking for achievement: it may affect productivity (the overall level of achievement in the school or class), and it may affect inequality (the distribution of achievement across the different tracks, classes, or groups). Although not all studies have reached the same conclusions about these outcomes, the weight of the evidence indicates that tracking tends to exacerbate inequality with little or no contribution to overall productivity. This occurs because gains for high achievers are offset by losses for low achievers. A compelling example of this pattern comes from Kerckhoff's (1986) study of ability grouping between and within schools in England and Wales. Kerckhoff used data from the National Child Development Study, which followed for more than 30 years all children born in the U.K. in the first week of March in 1958. He examined secondary school achievement in reading and mathematics among students enrolled in schools for high achievers (grammar schools), low achievers (secondary modern schools) and those of widely varying achievement levels (comprehensive schools). He also compared students assigned to high, middle, low, and mixed-ability classes within the different types of schools. Comparisons between and within schools told a consistent story: There were no overall benefits to average achievement in contexts that differentiated students for instruction as compared with mixedability contexts. However, sorting students into selective schools and classes was associated with increasing gaps between high and low achievers over time (see also Kerckhoff, 1993).

The comparison of tracking to mixed-ability teaching has received less attention in the U.S. because tracking has been nearly universal at the secondary level (Loveless, 1998). However, comparisons of ability-grouped and mixed-ability classes in middle school mathematics and science (Hoffer, 1992) and English (Gamoran \& Nystrand, 1994) in the U.S. have yielded the same pattern reported by Kerckhoff $(1986,1993)$. National survey analyses in the U.S. have also demonstrated that over the course of high school, students assigned to high and low tracks grow farther and farther apart in achievement (e.g., Heyns, 1974; Alexander, 
Cook, \& McDill, 1978; Gamoran, 1987a, 1992; Gamoran \& Mare, 1989; Lucas \& Gamoran, 2002).

Because track location is correlated with traditional bases of socioeconomic disadvantage, tracking not only widens achievement gaps but also reinforces social inequality (Oakes et al., 1992; Lucas \& Berends, 2002). In contrast to socioeconomic status, which has direct effects on track assignment, race and ethnicity affect track assignment indirectly. Minority students whose test scores and socioeconomic backgrounds match those of Whites are no less likely to be placed in high tracks (Gamoran \& Mare, 1989; Lucas \& Gamoran, 2002; Tach \& Farkas, 2006). However, because minority students tend to reach high school with lower test scores and less advantaged socioeconomic circumstances, tracking works to the disadvantage of minority students and contributes to achievement gaps.

As the demographic makeup of U.S. schools has changed, new patterns of inequality associated with tracking have become more salient. With regard to language minorities, Callahan (2005) argued that schools often conflate limited proficiency in English with limited ability to master academic content. As a result, English language learners are tracked into classes with modified curricula that are less rigorous than those of regular classes, which prevents these students from gaining access to advanced instruction even as their language skills develop. While Callahan supported these assertions with a study of a rural California school, Paul (2005) reached a similar conclusion based on her study of five diverse urban schools. Paul noted that enrollment in Algebra 1, the gateway to the college-preparatory curriculum, was stratified by race and ethnicity, with Asian American and White students enrolled in higher proportions and African American and Hispanic students enrolled in lower proportions. When English language learners enrolled in the same levels of algebra as fluent English speakers, they had similar rates of college-preparatory course work. Foreshadowing this work, Padilla and Gonzales (2001) argued that one reason recent Mexican immigrants outperform second-generation students is that the immigrants have spent less time in low tracks in U.S. schools.

New forms of tracking in the U.S. have exhibited patterns of inequality comparable to those of earlier forms. Using high school transcripts from a national sample of students, Lucas (1999) showed that students were grouped on a subject-by-subject basis rather than by broad curricular programs. Nevertheless, students' course levels tended to correlate across subject areas, and this more subtle version of tracking still resulted in achievement inequality. Mitchell and Mitchell (2005) demonstrated that multitrack, year-round schools also tended to stratify students by social origins. Both Lewis and Cheng (2006) and Mickelson and Everett (2008) found that the transformation of vocational education into career and technical education, though accompanied by greater emphasis on academic work within technical courses of study, still resulted in stratified class enrollments.

Generally, elementary and middle schools have seen a pattern of increasing inequality similar to that observed at the high school level (e.g., Rowan \& Miracle, 1983; Hoffer, 1992; Gamoran, Nystrand, Berends, \& LePore, 1995). Until recently, national data were available only at the secondary level, so it was not possible to examine the generalizability of patterns of inequality associated with elementary school ability grouping. However, recent analyses of data from a national sample of children who entered kindergarten in 1998 have confirmed the pattern of widening gaps for within-class reading groups in kindergarten (Tach \& Farkas, 2006). Using 
later waves of the same data, Lleras and Rangel (2009) reported similar findings for betweenclass ability grouping in Grades 1 and 3.

In an exception to the general pattern, Slavin (1987) reported (based on a synthesis of research on elementary school grouping) positive effects of within-class grouping in mathematics for students in low-ranked as well as high-ranked groups. Slavin also noted that when students were regrouped for specific subjects, rather than being tracked for the entire school day, ability grouping had positive effects for students at all achievement levels. On the basis of these findings, Slavin proposed that elementary school ability grouping can have positive effects when (a) assignment is based on criteria relevant to the subject, (b) students can be moved from one group to another as appropriate to their progress, and (c) curriculum and instruction are differentiated to meet the needs of students assigned to the different groups.

Slavin's conclusions have recently been affirmed by Connor and her colleagues (Connor, Morrison, Fishman, Schatschneider, \& Underwood, 2007; Connor et al., 2009). Connor's work shows that small reading groups can be used effectively to tailor reading instruction to students' needs. In a randomized comparison, Connor et al. (2007) reported that students taught by teachers who arranged students into reading groups according to carefully assessed student performance levels, and who aimed instruction at students' specific needs, performed much better by the end of first grade than those taught by teachers who did not have access to this systematic approach to assigning students and differentiating instruction. Though based on less precise evidence, Tomlinson et al. (2003) advanced similar claims about the value of withinclass differentiation of instruction as a strategy for effective teaching of students with varied interests and skills.

\section{Challenges in Measuring the Effects of Tracking}

Two methodological challenges have confronted researchers studying the impact of tracking and ability grouping on student achievement. One challenge has been to measure accurately students' group and track locations. At the secondary level, research from the 1970s and 1980s often relied on students to report whether their curricular programs could best be described as academic/college-preparatory, vocational, or general. This social-psychological measure of tracking was useful as an indicator of students' perceptions but did not necessarily represent students' actual learning opportunities. Lucas (1999) developed a structural measure of track location by using students' transcripts to identify tracks based on the courses students had taken. Lucas and Gamoran (2002) showed that structural and social-psychological dimensions of tracking had independent effects on student achievement, but both contributed to achievement gaps. Other researchers have used network analysis techniques to identify tracks through the configuration of courses in which students enroll (Friedkin \& Thomas, 1997; Heck, Price, \& Thomas, 2004), reaching similar conclusions about tracking and inequality. More recent studies have also uncovered inequality using teacher reports to distinguish among ability groups at high, middle, and low levels (Carbonaro, 2005; Tach \& Farkas, 2006).

The second methodological challenge has been to distinguish the effects of track assignment from the effects of preexisting differences among students assigned to different tracks. Obviously, students in high and low tracks are on different achievement trajectories to begin with; that is how they come to be located in different tracks. All the analyses discussed 
here have controlled for prior achievement and social background, but due to unreliability and measurement error, not all preexisting conditions may have been captured by the controls, and the potential for selectivity bias remains. Researchers have endeavored to respond to this challenge in two ways. First, a few studies, mainly prior to 1970, used random assignment to tracked or untracked settings to rule out selectivity bias (Slavin, 1987, 1990). These studies yielded widely varying estimates of track effects that centered around zero. Because they provided little information on what was going on inside the tracks, it is difficult to assess the generalizability of these small and long-ago experiments. In at least some cases of zero effects, teachers designed instruction and curriculum to be the same across tracks, in contrast to the real world where tracking is typically accompanied by curricular and instructional differentiation. These findings led Gamoran (1987b) to argue that the effects of tracking depend on how it is implemented, a conclusion later supported by both case study (Gamoran, 1993) and survey analyses (Gamoran, 1992).

Second, researchers have used econometric techniques to mitigate selectivity bias. Gamoran and Mare (1989) estimated endogenous switching regressions that model track assignment and track effects simultaneously, allowing for correlated errors among unobserved predictors of assignment and outcomes. Their results, which focused on mathematics achievement and high school completion for the high school class of 1982, indicated that the pattern of increasing inequality observed in standard regression analyses with rich controls was upheld in the more complex technique. Lucas and Gamoran (2002) replicated these results for the high school class of 1992 as well as the class of 1982, and with course-based as well as selfreported indicators of track location. Again, the main findings were upheld. However, Betts and Shkolnik (2000), who estimated both propensity models and two-stage least squares regressions models of track effects on mathematics achievement, concluded that the differential effects of tracking for students in high and low tracks were much smaller than reported in earlier studies that relied on simple regressions. Figlio and Page (2002) similarly called into question the negative effects of tracking on secondary school math achievement on the basis of two-stage least squares regression models. ${ }^{2}$ While it is premature to conclude that tracking is not harmful to low achievers, these studies, combined with the early experimental research, suggest the effects may be smaller than is typically assumed. Since Gamoran and Mare focused on broad curricular tracking while Betts and Shkolnik and Figlio and Page examined between-class ability grouping, the findings may also indicate that the latter is less consequential for inequality than the former.

\footnotetext{
${ }^{2}$ The models estimated by Betts and Shkolnik (2000) and Figlio and Page (2002) rely on very strong assumptions, so their results should be interpreted with particular caution. Betts and Shkolnik's conclusions rest on comparisons of classes at similar ability levels as reported by teachers but located in schools that differed on whether the principal reported that tracking was used for mathematics. Yet teacher reports of class ability levels may reflect between-class ability grouping regardless of the principal's report. Figlio and Page (2002) used as instruments for track assignment indicators that, on the face of it, seem far-fetched: two- and three-way interactions between the number of courses required for graduation, the number of schools in the county, and the fraction of voters in the county who voted for President Reagan in 1984. Weak instruments would undermine the estimates of track effects and could bias them towards zero.
} 


\section{Mechanisms of Track Effects on Achievement}

With few exceptions, the evidence indicates that tracking tends to magnify inequality. Why is that the case? Conceptually, researchers have identified mechanisms of social comparison as well as differentiated instruction, but empirically it appears that instructional variation across tracks and groups at different levels is the more prominent reason for increases in achievement gaps between tracks. A number of studies have concluded that students in high tracks encounter more challenging curricula, move at a faster pace, and are taught by more experienced teachers with better reputations, while students in low tracks encounter more fragmented, worksheet-oriented, and slower-paced instruction provided by teachers with less experience or clout (for reviews, see Oakes et al., 1992; Gamoran, 2004). These findings have emerged at the elementary, middle, and high school levels. Instructional differences reflect not only what teachers do in classrooms, but also how students respond. A recent finding along these lines comes from the work of Carbonaro (2005), who demonstrated that achievement diverges in part because high-track students put forth more effort on their school work than low-track students. While this finding reflected, in part, low-track students' responses to instruction that was less intellectually stimulating than the instruction given to high-track classes, it also stemmed from differences that students brought with them to class.

Other new examples of instructional mediation of the effects of tracking come from both hypothesis testing and interpretive research. In a study of 64 middle and high school English classes, Applebee, Langer, Nystrand, and Gamoran (2003) reported greater use of discussionbased approaches to literature instruction in high-ability than in low-ability classes, and this difference accounted for just over one third of the effect of ability group assignment on writing performance. Discussion-based approaches included (a) using authentic questions (questions with no pre-specified answer) and "uptake" questions (questions building on prior statements), (b) encouraging open discussion, (c) drawing in multiple perspectives ("envisionment building"), and (d) initiating conversations that connected different curricular topics. Watanabe (2008) reported parallel instructional differences based on in-depth analyses of 68 hours of classroom observation in two teachers' language arts classes. In high-ability classes, she found more engagement with challenging and meaningful curricula, more writing assignments in more diverse genres, and more feedback from teachers, as contrasted with more emphasis on test preparation in low tracks.

Findings that instructional differentiation accounts for much of the effect of tracking have led some observers to conclude that tracking per se does not generate inequality, but rather inequality has emerged because of the way in which tracking has been implemented (e.g., Hallinan, 1994). If instruction in low tracks could be effectively geared toward students' needs, this argument states, then tracking might mitigate rather than exacerbate inequality. While reasonable in principle, this goal has proven difficult to accomplish in practice, and there are few examples of effective instruction in low-track classes (for exceptions, see Gamoran, 1993; Gamoran \& Weinstein, 1998). At the same time, it is important to acknowledge that most studies of ability grouping and curriculum tracking have found that high-achieving students tend to perform better when assigned to high-level groups than when taught in mixed-ability settings. Proponents of tracking tend to emphasize the benefits of high-level classes for high-achieving students with little attention to implications for inequality, while critics tend to focus on the inequality without acknowledging the effects for high achievers. As a result, proponents and 
critics are apt to talk past one another with little chance for resolution, and student assignment policies often lurch from one system to another without recognition of the strengths and shortcomings of each (Boaler, Wiliam, \& Brown, 2000; Gamoran, 2002; Tsuneyoshi, 2004).

\section{New International Research on Tracking and Achievement}

An emerging body of international work is largely consistent with the findings from the U.S. and the U.K. Perhaps the most revealing results come from new cross-national studies of international achievement data. Analyses from PISA ${ }^{3}$ 1999, a study conducted in 28 OECD countries, indicated that countries with more differentiated school systems are characterized by greater inequality by social origins in reading achievement (OECD, 2002). Hanushek and Woessmann (2006) reinforced this conclusion by comparing 20 countries that participated in both PISA and PIRLS, ${ }^{4}$ showing that achievement inequality tends to increase more between the primary and secondary grades in countries that practice early tracking than in countries that do not. Similarly, research on 24 countries that participated in TIMSS ${ }^{5} 2003$ at Grades 4 and 8 showed that countries that rely on between-class ability grouping for mathematics exhibit more growth in achievement inequality from Grades 4 to 8 than countries that make less use of ability grouping (Huang, in press). These findings are consistent with numerous single-nation studies showing that tracking tends to reinforce inequality.

A recurring theme in the international work is that grouping and tracking come in many forms, a point that is easily missed when one focuses on a single nation. For example, countries differ on whether tracking occurs largely between schools (e.g., Japan, Germany), within schools (Australia, Belgium, Israel, U.S.), or both (Taiwan, U.K.). In these different tracking systems, the scope of tracking may be wide (covering many subjects) or narrow (implemented on a subjectby-subject basis). Countries also differ on whether differentiation is introduced early or late and whether the system is flexible enough to allow mobility between tracks. These structural differences were anticipated by Sørensen (1970) but have been greatly elaborated as international differences have become evident (LeTendre, Hofer, \& Shimizu, 2003). What is striking about the variation in the forms of tracking, however, is that the results are broadly similar: where tracking systems are present, achievement tends to diverge, and to reinforce initial differences by social class. New studies from Japan (Ono, 2001), Korea (Park, 2009), South Africa (Hoadley, 2008), Israel (Ayalon, 2006), Germany (Cheng, Martin, \& Werum, 2007), Belgium (Van Houtte, 2004; Van de gaer, Pustjens, Van Damme, \& De Munter, 2006), and the U.K. (Boaler et al., 2000; Ireson, Hallam, Hack, Clark, \& Plewis, 2002; Ivinson \& Duveen, 2005) all identify aspects of increasing inequality associated with grouping between or within schools. Moreover, as ethnic minority groups increase in size and ethnic inequality is increasingly recognized in nations that were formerly relatively homogeneous (such as European countries with new populations of guest workers), researchers are finding that tracking reinforces ethnic inequalities (Cheng et al., 2007). Ivinson and Duveen (2005) in the U.K. and Ayalon (2006) in Israel also demonstrated that horizontal differentiation (i.e., divisions between subjects) tend to stratify students by social origins just as does vertical differentiation (divisions between levels). Finally, Van Houtte (2004)

\footnotetext{
${ }^{3}$ Program on International Student Assessment.

${ }^{4}$ Progress in International Reading Literacy Study.

${ }^{5}$ Trends in International Mathematics and Science Survey.
} 
presented findings from Belgium that supported the conclusion from U.S. research that track effects are largely driven by instructional differences.

Within this common framework, interesting differences also emerge. For example, in countries with well-articulated standards tied to curriculum and assessment, the harmful effects of tracking may be mitigated by incentives for success in lower level classes. Broaded (1997) reported that high-stakes exams targeted at different achievement levels in Taiwan led all students, including those in low tracks, to work hard at their studies, and as a result, tracking contributed to smaller achievement inequalities. Similarly in the case of Israel, Ayalon and Gamoran (2000) found that schools with multiple ability levels within college-preparatory mathematics programs tended to have less inequality by social origin than schools with only a single level. They attributed this result to meaningful incentives attached to lower level mathematics courses, which, like higher level courses, led to high-stakes assessments at the end of high school. Likewise, a secondary curriculum reform in Scotland that raised standards for lower level students resulted in declining inequality of achievement over time (Gamoran, 1996), and in Australia, a reform in secondary English that reduced the number of tracks and simultaneously raised standards in low tracks may have boosted test scores overall (Stanley \& MacCann, 2005). In the U.S., a parallel finding is that Catholic schools, which place more academic demands on students in lower tracks than public schools, tend to exhibit less achievement inequality between tracks than public schools (Gamoran, 1992). These findings reinforce Broaded's (1997) conclusion that the impact of tracking is context-dependent and suggest that, in principle, tracking's pernicious effects on low achievers can be reduced or eliminated. Thus far, however, attempts to use ability grouping to raise achievement in the context of high standards in U.S. public schools have met with limited success (Sandholtz, Ogawa, \& Scribner, 2004; Lewis \& Cheng, 2006; Mickelson \& Everett, 2008).

\section{New Insights from U.S. Research on Detracking}

More than 15 years ago, Oakes (1992) insightfully identified three challenges faced by detracking efforts:

- Normative challenges, based on long-standing beliefs that young persons differ by ability and that schools should be structured to address those differences;

- Political challenges, reflecting the difficulty of overcoming vested interests in tracking, such as those held by parents who are ambitious for their high-achieving children and by teachers who enjoy teaching honors classes; and

- Technical challenges, reflecting the difficulty of instructing students of widely varying levels of performance, a task for which few teachers are prepared.

Most of the emphasis in Oakes' subsequent work (see especially the 2005 edition of her classic book, Keeping Track) and that of her colleagues and students (e.g., Wells \& Serna, 1996; Oakes \& Wells, 1998; Welner, 2001; Yonezawa, Wells, \& Serna, 2002) has been on the normative and political challenges, reasoning that if these challenges could be surmounted, the technical difficulties could be easily overcome. Recent evidence, however, suggests the opposite: failure to solve the technical problems of mixed-ability teaching is a major impediment to addressing the 
normative and political challenges. While the technical challenges have defied easy solution, recent work has identified conditions under which effective teaching in mixed-ability contexts may be more successful than in the past.

\section{Challenges of Detracking}

Loveless's (1999) analysis of detracking reforms in California and Massachusetts revealed substantial resistance from teachers who believed that they were not equipped to successfully instruct students at widely varying performance levels within the same classrooms. Teachers' attitudes towards detracking tended to differ by subject matter, with mathematics and foreign language teachers more resistant than teachers in other subjects due to beliefs about the sequential nature of knowledge in these disciplines (see also Ball, 1987; Gamoran \& Weinstein, 1998). Even in social studies, however, a subject area that might be viewed as particularly conducive to mixed-ability teaching because of the potential for discussion of topics from diverse viewpoints, detracking efforts have run into technical difficulties. One case study found that teachers struggled to engage students in classes with widely varying achievement levels; low-achieving students had difficulty with assignments while high-achieving students were bored (Rosenbaum, 1999). In another study, Rubin (2008) found that detracking in social studies seemed to work well in a middle-class suburban school with a relatively homogeneous population, as teachers emphasized active learning and differentiated assignments for students at different performance levels. However, detracked social studies classes appeared less effective in a more diverse school, where teachers aimed more for relevance than for high standards; and in an inner-city school with a low-income population, detracking resulted in a highly routinized curriculum with little challenge for students. Rubin's observations in the inner-city school mirrored earlier findings by Gamoran and Weinstein (1998) from an urban school in which tracking in mathematics was eliminated by diluting the curriculum in mixed-ability classes to a level that all students could follow, with the result that teachers complained students were not being prepared to move to more advanced mathematics.

Ironically, findings from all three of these case studies (Rosenbaum, 1999; Rubin, 2008; Gamoran \& Weinstein, 1998) suggest that high-achieving minority students may have the most to lose when detracking is unsuccessful. These students are often found in urban schools where detracking has not resulted in challenging instruction in mixed-ability classes, and they may lack the support outside of school to succeed in the absence of a challenging curriculum. Rubin (2003) brought this problem to life based on interviews and observations of a high-achieving minority student in a detracked school who socialized with a small group of less academically oriented peers, to the detriment of her academic work.

Some schools have attempted to reduce the use of tracking by allowing students to select their own track assignments. Recent case studies suggest, however, that student choice is not an effective detracking mechanism, because students tend to sort themselves into classes in much the same way as a traditional tracking system, and with the corresponding results for social class and race/ethnic divisions (Watanabe, 2007). Yonezawa et al. (2002) proposed that differential access to information and varied aspirations among students contributed to this pattern. In addition, they noted that minority students preferred classes in which they were not racially isolated and in which their cultural backgrounds were valued. These findings reflect the familiar tension between commonality and differentiation: while there may be benefits to students' 
academic performance from pursuing a common curriculum, students are motivated by their interests and social concerns, which may result in ethnic as well as academic divisions.

Boaler and Staples (2008) uncovered mixed success in another detracking case study. Initially, achievement gains appeared in one detracked school as compared to two others that did not detrack. However, the gains were not sustained over the 3 years of the study. Moreover, the achievement benefits were not evident on the high-stakes state standardized test, and it is difficult at any rate to attribute achievement trends to any single reform in a sample of three schools. Nonetheless, the study is enticing in its call for further examination of instruction in detracked schools.

\section{The Technical Challenge: Differentiated Instruction in Mixed-Ability Classes}

Not all cases of mixed-ability teaching have met with frustration. In the same research project that uncovered a case of diluted curriculum in a detracked school (discussed in the last section), Gamoran and Weinstein (1998) identified a successful instance of detracking in secondary school mathematics. In this urban, East Coast high school in which half the students were eligible to receive free or reduced-price lunch, student performance on authentic assessments was the highest of all the 25 highly restructured schools from which this case was drawn. In this school, mathematics and science instruction were integrated in the same class, and student work was project-oriented; for example, researchers observed students applying principles of mathematics and physics in completing an assignment to design rides in an amusement park. Students were assessed based on portfolios of work in a variety of subjects, and expectations for students took into account their progress as well as the levels of excellence they had attained. Moreover, students were expected to have mastered elementary mathematics and if they had not, a Saturday tutoring program was available to help them along. Key elements that supported a rigorous curriculum in a mixed-ability setting in this school were small classes (limited to 15 students), the supplemental tutoring program, a visionary leader who had selected a staff with congruent attitudes, and the opportunity to interview students prior to students' admission to the school.

More recently, Burris and her colleagues (Burris, Heubert, \& Levin, 2006; Burris, Wiley, Welner, \& Murphy, 2008) also identified cases of high achievement in mathematics that resulted from a move to mixed-ability teaching. The authors used an interrupted time series design to assess the impact of the reform, comparing the achievement trajectories of schools before the reform with their trajectories afterward, as well as with the trajectories of other schools that did not undergo the reform over the same period. At the middle school level in this New York school district (Burris et al., 2006), teachers implemented an accelerated curriculum for all students, paired with a supplemental workshop to support students who had trouble keeping up. They also introduced common preparation time for teachers and increased the use of calculators in class. At the high school level, the low-track non-Regents class was eliminated, and all students were placed in mathematics classes that led to the Regents diploma. Students who struggled with this class had available to them a supplementary class that met three times each week. At both levels, student achievement rose following the introduction of the reform. Achievement gaps narrowed as low achievers gained more than high achievers, but there was no evidence that high achievers suffered in their performance as a result of the reform. Achievement gains did not reflect increasing high school dropout rates; on the contrary, dropout rates declined over the period of 
the reform. It should be noted that this case involved an economically advantaged school district with relatively few high-needs students compared to other New York school districts. The supplemental class also provided about 50\% more mathematics instruction to low-achieving students.

The new research by Burris and colleagues is extremely important because it demonstrates that detracking can result in gains for low achievers without the losses for high achievers observed in earlier attempts. As in the case study reported by Gamoran and Weinstein (1998), however, success was based in part on favorable circumstances, particularly the resources that enabled the school to offer extra mathematics instruction for struggling students. This accomplishment calls for replication in other contexts to assess its broader viability.

\section{Conclusion: New Directions for Research and Practice}

While definitive solutions remain elusive, the present time is witness to exciting new prospects for balancing the aims of commonality and differentiation in grouping students for instruction. Recent findings lend support to two approaches that merit further experimentation in research and practice: Raising standards for low achievers in differentiated classrooms; and providing differentiated learning opportunities in mixed-ability classrooms. The key to evaluating both approaches will be careful monitoring of the nature and quality of instruction and the relation between instruction and achievement, however students are arranged for class.

\section{Raising Standards for Low-Achieving Students}

The practical conclusion from years of tracking research that low-level, dead-end courses should be eliminated is no longer seriously debated. High school courses such as general math and business English do not prepare students for postsecondary opportunities and are less effective than regular courses such as algebra and college-preparatory English, even for students with low skill levels in these areas. This conclusion still leaves open the possibility, however, that meaningful instruction at all skill levels could make differentiated classes an effective way to organize students for learning.

Critics of tracking such as Oakes (2005) argue that because tracking is inherently stratifying, it is just not possible to offer effective instruction to low-achieving students in ability-grouped classes. Indeed, examples of high-quality instruction in low-ability classes are rare. Yet recent international research shows that differentiated class settings for low achievers can be effective when they are tied to meaningful outcomes such as assessments that are aligned to the curriculum and provide access to jobs and further education. Studies from Taiwan (Broaded, 1997) and Israel (Ayalon \& Gamoran, 2000) demonstrated that differentiation within academic programs in which meaningful instruction and valued incentives are present at all ability levels can result in less inequality than systems of fewer levels in which low-achieving students lack access to meaningful incentives. Other research from Scotland (Gamoran, 1996) and Australia (Stanley \& MacCann, 2005) observed that the negative effects of tracking for low achievers diminished when the degree of tracking was reduced and when academic standards in the lower level classes were elevated. The common ingredient in all four cases was a meaningful assessment that had value for students in lower level as well as higher level classes. 
Do these findings have any bearing on the U.S., where classes for low achievers typically lack meaningful incentives for effort or performance? The finding that Catholic schools obtain smaller achievement gaps between tracks than public schools by providing more rigorous instruction in low tracks, and cases of successful low-track instruction in Catholic schools (Gamoran, 1993) and restructured public schools (Gamoran \& Weinstein, 1998), merely show that exceptions are possible, not that making low-track instruction more effective by raising standards overall is a viable reform strategy for the U.S. The current emphasis on test-based accountability in the U.S. might, in principle, lead schools to create effective low-ability classes in order to meet accountability requirements. However, the evidence so far suggests that accountability-driven tracking is no more effective for low achievers than other forms of tracking (Sandholtz, Ogawa, \& Scribner, 2004).

Based on insights from the international work, one can identify at least three elements that would need to change to make low-track classes more effective:

1. The assessments toward which students were striving would need to be tied to futures that were more visibly meaningful to students than is currently the case. At present, students are prodded to perform on multiple-choice tests whose underlying standards are not evident and that demand fragmented knowledge rather than coherent mastery of subject matter that has relevance beyond the test itself.

2. The assessments would need to offer incentives for students as well as schools. At present, schools are held accountable for student performance, but the students themselves are not. Positive incentives — for example, access to jobs and/or postsecondary education—would need to be offered, not merely negative sanctions such as denial of a high school diploma.

3. The relation between the course curriculum and the assessment would need to be tighter than has typically been the case in the U.S.

\section{Differentiating Instruction in Mixed-Ability Settings}

Although detracking remains a challenging solution with more examples of failure than success, the findings of recent studies are positive enough to warrant further efforts. An examination of reports of effective instruction in mixed-ability classes yields several common ingredients. First, the success stories all recognize that students differ in the skills and interests they bring to class. Successful cases reported by Burris, Gamoran, Connor, and their colleagues are not instances in which teachers acted as if students were all alike. Instead, teachers responded to variation among students in their teaching. Second, and correspondingly, all the successful cases involved differentiated instruction within the mixed-ability setting. In the secondary school cases reported by Burris, Gamoran, and their colleagues, differentiation involved supplemental instruction that was available for students who struggled with class materials. In Connor's elementary school research, differentiation meant carefully analyzing students' skill levels, matching skills to particular instructional strategies, and arranging students for instruction within classes in such a way as to match the skill levels with instructional approaches. Third, teachers in each of these cases had access to important resources that allowed them to supplement instruction and tailor it to students' needs. Future efforts would do well to keep these elements in mind. 


\section{Combining Research on Tracking with Research on Teaching}

After a century of research on tracking and ability grouping, one might expect to see a definitive answer to the question of how best to organize students for instruction. Yet the dilemma persists, because the goals of commonality and differentiation lie in uneasy proximity to one another, because every approach has disadvantages as well as advantages, and because the consequences of different solutions vary by context. Research in the last decade has made important progress, however, by focusing on the instruction provided to students assigned to classes in different ways. Ultimately, how students are arranged matters less than the instruction they encounter, so bringing together research on tracking with research on teaching offers the most useful way to continue to shed light on this topic of continuing interest. 


\section{Tracking and Inequality}

\section{References}

Alexander, K. L., Cook, M. A., \& McDill, E. L. (1978). Curriculum tracking and educational stratification. American Sociological Review, 43, 47-66.

Applebee, A. N., Langer, J., Nystrand, M., \& Gamoran, A. (2003). Discussion-based approaches to developing understanding: Classroom instruction and student performance in middle and high school English. American Educational Research Journal, 40, 685-730.

Ayalon, H. (2006). Nonhierarchical curriculum differentiation and inequality in achievement: A different story or more of the same? Teachers College Record, 108, 1186-1213.

Ayalon, H., \& Gamoran, A. (2000). Stratification in academic secondary programs and educational inequality: Comparison of Israel and the United States. Comparative Education Review, 44, 54-80.

Ball, S. J. (1987). The micro-politics of the school: Towards a theory of school organization. London: Methuen.

Betts, J. R., \& Shkolnik, J. L. (2000). The effects of ability grouping on student achievement and resource allocation in secondary schools. Economics of Education Review, 19, 1-15.

Boaler, J., \& Staples, M. (2008). Creating mathematical futures through an equitable teaching approach: The case of Railside School. Teachers College Record, 110, 608-645.

Boaler, J., Wiliam, D., \& Brown, M. (2000). Students’ experiences of ability grouping: Disaffection, polarisation, and the construction of failure. British Educational Research Journal, 26, 631-648.

Broaded, C. M. (1997). The limits and possibilities of tracking: Some evidence from Taiwan. Sociology of Education, 70, 36-53.

Burris, C. C., Heubert, J. P., \& Levin, H. M. (2006). Accelerating mathematics achievement using heterogeneous grouping. American Educational Research Journal, 43, 105-136.

Burris, C. C., Wiley, E., Welner, K., \& Murphy, J. (2008). Accountability, rigor, and detracking: Achievement effects of embracing a challenging curriculum as a universal good for all students. Teachers College Record, 110, 571-607.

Callahan, R. (2005). Tracking and high school English learners: Limiting opportunity to learn. American Educational Research Journal, 42, 305-328.

Carbonaro, W. (2005). Tracking, students’ effort, and academic achievement. Sociology of Education, 78, 27-49.

Cheng, S., Martin, L., \& Werum, R. E. (2007). Adult social capital and track placement of ethnic groups in Germany. American Journal of Education, 114, 41-74. 


\section{Tracking and Inequality}

Connor, C. M., Morrison, F. J., Fishman, B. J., Schatschneider, C., \& Underwood, P. (2007). The early years: Algorithm-guided individualized reading instruction. Science, 315, 464-465.

Connor, C. M., Piasta, S. B., Fishman, B., Glasney, S., Schatschneider, C., Crowe, E., et al. (2009). Individualizing student instruction precisely: Effects of child by instruction interactions on first graders’ literacy development. Child Development, 80, 77-100.

Figlio, D. N., \& Page, M. E. (2002). School choice and the distributional effects of ability tracking: Does separation increase inequality? Journal of Urban Economics, 51, 497514.

Friedkin, N. E., \& Thomas, S. L. (1997). Social positions in schooling. Sociology of Education, 70, 239-255.

Gamoran, A. (1987a). The stratification of high school learning opportunities. Sociology of Education, 60, 135-155.

Gamoran, A. (1987b). Organization, instruction, and the effects of ability grouping: Comment on Slavin’s “best-evidence synthesis.” Review of Educational Research, 57, 341-345.

Gamoran, A. (1992). The variable effects of high school tracking. American Sociological Review, 57, 812-828.

Gamoran, A. (1993). Alternative uses of ability grouping in secondary schools: Can we bring high-quality instruction to low-ability classes? American Journal of Education, 101, 122.

Gamoran, A. (1996). Curriculum standardization and equality of opportunity in Scottish secondary education, 1984-1990. Sociology of Education, 29, 1-21.

Gamoran. A. (2002). CES briefing: Standards, inequality, and ability grouping. Edinburgh, Scotland: Centre for Educational Sociology.

Gamoran, A. (2004). Classroom organization and instructional quality. In M. C. Wang \& H. J. Walberg (Eds.), Can unlike students learn together? Grade retention, tracking, and grouping (pp. 141-155). Greenwich, CT: Information Age.

Gamoran, A., \& Berends, M. (1987). The effects of stratification in secondary schools: Synthesis of survey and ethnographic research. Review of Educational Research, 57, 415-435.

Gamoran, A., \& Mare, R. D. (1989). Secondary school tracking and educational inequality: Compensation, reinforcement, or neutrality? American Journal of Sociology, 94, 11461183.

Gamoran, A., \& Nystrand, M. (1994). Tracking, instruction, and achievement. International Journal of Educational Research, 21, 217-231. 


\section{Tracking and Inequality}

Gamoran, A., Nystrand, M., Berends, M., \& LePore, P. C. (1995). An organizational analysis of the effects of ability grouping. American Educational Research Journal, 32, 687-715.

Gamoran, A., \& Weinstein, M. (1998). Differentiation and opportunity in restructured schools. American Journal of Education, 106, 385-415.

Hallam, S. (2002). Ability grouping in schools. London: University of London Institute of Education.

Hallinan, M. T. (1994). Tracking: From theory to practice. Sociology of Education, 67, 79-84.

Hanushek, E. A., \& Woessmann, L. (2006). Does educational tracking affect performance and inequality? Differences-in-differences evidence across countries. The Economic Journal, 116, C63-C76.

Harlen, W., \& Malcolm, H. (1997). Setting and streaming: A research review. Edinburgh: Scottish Council for Research in Education.

Heck, R. H., Price, C., \& Thomas, S. L. (2004). Tracks as emergent structures: A network analysis of student differentiation in a high school. American Journal of Education, 110, 321-353.

Heyns, B. (1974). Selection and stratification within schools. American Journal of Sociology, 79, 1434-1451.

Hoadley, U. (2008). Social class and pedagogy: A model for the investigation of pedagogic variation. British Journal of Sociology of Education, 29, 63-78.

Hoffer, T. B. (1992). Middle school ability grouping and student achievement in science and mathematics. Educational Evaluation and Policy Analysis, 14, 205-227.

Huang, M-H. (in press). Classroom homogeneity and the distribution of student math performance: A country-level fixed-effects analysis Social Science Research.

Ireson, J., Hallam, S., Hack, S., Clark, H., \& Plewis, I. (2002). Ability grouping in English secondary schools: Effects on attainment in English, mathematics, and science. Educational Research and Evaluation, 8, 299-318.

Ivinson, G., \& Duveen, G. (2005). Classroom structuration and the development of social representations of the curriculum. British Journal of Sociology of Education, 26, 627642.

Kerckhoff, A. (1986). Effects of ability grouping in British secondary schools. American Sociological Review, 51, 842-858.

Kerckhoff, A. (1993). Diverging pathways: Social structure and career deflections. Cambridge, England: Cambridge University Press. 
Kulik, C.-L., \& Kulik, J. A. (1982). Effects of ability grouping on secondary school students: A meta-analysis of evaluation findings. American Educational Research Journal, 19, 415428.

LeTendre, G. K., Hofer, B. K., \& Shimizu, H. (2003). What is tracking? Cultural expectations in the United States, Germany, and Japan. American Educational Research Journal, 40, 4389.

Lewis, T., \& Cheng, S-Y. (2006). Tracking, expectations, and the transformation of vocational education. American Journal of Education, 113, 67-99.

Lleras, C., \& Rangel, C. (2009). Ability grouping practices in elementary school and African American/Hispanic achievement. American Journal of Education, 115, 279-304.

Loveless, T. (1998). The tracking and ability grouping debate. Washington, DC: Fordham Institute.

Loveless, T. (1999). The tracking wars: State reform meets school policy. Washington, DC: Brookings Institution Press.

Lucas, S. R. (1999). Tracking inequality. New York: Teachers College Press.

Lucas, S. R., \& Berends, M. (2002). Sociodemographic diversity, correlated achievement, and de facto tracking. Sociology of Education, 75, 328-348.

Lucas, S. R., \& Gamoran, A. (2002). Track assignment and the black-white test score gap: Divergent and convergent evidence from 1980 and 1990 sophomores. In T. Loveless (Ed.), Closing the gap: Promising strategies for reducing the achievement gap (pp. 171198). Washington, DC: Brookings Institution Press.

Mickelson, R. A., \& Everett, B. J. (2008). Neotracking in North Carolina: How high school courses of study reproduce race and class-based stratification. Teachers College Record, 110, 535-570.

Mitchell, R. E., \& Mitchell, D. E. (2005). Student segregation and achievement tracking in yearround schools. Teachers College Record, 107, 529-562.

Oakes, J. (1992). Can tracking research inform practice? Technical, normative, and political considerations. Educational Researcher, 21(4), 12-22.

Oakes, J. (2005). Keeping track: How schools structure inequality ( $2^{\text {nd }}$ ed.). New Haven, CT: Yale University Press.

Oakes, J., Gamoran, A., \& Page, R. N. (1992). Curriculum differentiation: Opportunities, outcomes, and meanings. In P. W. Jackson (Ed.), Handbook of research on curriculum (pp. 570-608). New York: Macmillan. 
Oakes, J., \& Wells, A. S. (1998). Detracking for high student achievement. Educational Leadership, 55(6), 38-41.

OECD (Organisation for Economic Co-operation and Development). (2002). Education policy analysis. Paris: Author.

Ono, H. (2001). Who goes to college? Features of institutional tracking in Japanese higher education. American Journal of Education, 109, 161-195.

Padilla, A. M., \& Gonzales, R. (2001). Academic performance of immigrant and U.S.-born Mexican heritage students: Effects of schooling in Mexico and bilingual/English language instruction. American Educational Research Journal, 38, 727-742.

Park, H. (2009, March). Growing curriculum differentiation and its implications for inequality in Korea. Paper presented at the annual meeting of the Association of Asian Studies, Chicago.

Paul, F. G. (2005). Grouping within Algebra I: A structural sieve with powerful effects for lowincome, minority, and immigrant students. Educational Policy, 19, 262-282.

Powell, A. G., Farrar, E., \& Cohen, D. K. (1985). The shopping mall high school. Boston: Houghton Mifflin.

Rosenbaum, J. E. (1999). If tracking is bad, is detracking better? American Educator, 47, 24-29.

Rowan, B., \& Miracle, A. W., Jr. (1983). Systems of ability grouping and the stratification of achievement in elementary schools. Sociology of Education, 56, 133-144.

Rubin, B. C. (2003). Unpacking detracking: When progressive pedagogy meets students' social worlds. American Educational Research Journal, 40, 539-573.

Rubin, B. C. (2008). Detracking in context: How local constructions of ability complicate equitygeared reform. Teachers College Record, 110, 646-699.

Sandholtz, J. H., Ogawa, R. T., \& Scribner, S. P. (2004). Standards gap: Unintended consequences of local standards-based reform. Teachers College Record, 106, 11771202.

Slavin, R. E. (1987). Ability grouping and achievement in elementary schools: A best-evidence synthesis. Review of Educational Research, 57, 293-336.

Slavin, R. E. (1990). Achievement effects of ability grouping in secondary schools: A bestevidence synthesis. Review of Educational Research, 60, 471-499.

Sørensen, A. B. (1970). Organizational differentiation of students and educational opportunity. Sociology of Education, 43, 355-76. 


\section{Tracking and Inequality}

Stanley, G., \& MacCann, R. G. (2005). Removing incentives for “dumbing down” through curriculum re-structure and additional study time. Educational Policy Analysis Archives, 13, 1-10.

Tach, L. M., \& Farkas, G. (2006). Learning-related behaviors, cognitive skills, and ability grouping when school begins. Social Science Research, 35, 1048-1079.

Tomlinson, C. A., Brighton, C., Hertberg, H., Callahan, C. M., Moon, T. R., Brimijoin, K., et al. (2003). Differentiating instruction in response to student readiness, interest, and learning profile in academically diverse classrooms: A review of literature. Journal for the Education of the Gifted, 27, 119-145.

Tsuneyoshi, R. (2004). The new Japanese educational reforms and the achievement "crisis" debates. Educational Policy, 18, 364-394.

Van de gaer, E., Pustjens, H., Van Damme, J., \& De Munter, A. (2006). Tracking and the effects of school-related attitudes on the language achievement of boys and girls. British Journal of Sociology of Education, 27, 293-309.

Van Houtte, M. (2004). Tracking effects on school achievement: A quantitative explanation in terms of the academic culture of school staff. American Journal of Education, 110, 354388.

Watanabe, M. (2007). Lessons from a teacher inquiry group about tracking: Perceived student choice in course-taking and its implications for detracking reform. Teachers College Record, 109, 2136-2170.

Watanabe, M. (2008). Tracking in the era of high-stakes state accountability reform: Case studies of classroom instruction in North Carolina. Teachers College Record, 110, 489-533.

Wells, A. S., \& Serna, I. (1996). The politics of culture: Understanding local political resistance to detracking in racially mixed schools. Harvard Educational Review, 66, 93-118.

Welner, K. G. (2001). Legal rights, local wrongs: When community control collides with educational equity. New York: SUNY Press.

Yonezawa, S., Wells, A. S., \& Serna, I. (2002). Choosing tracks: "Freedom of choice” in detracked schools. American Educational Research Journal, 39, 37-67. 